\title{
THE PHYSIOLOGICAL AND QUALITY RESPONSE OF PELARGONIUM GRAVEOLENS (L.) GROWN ON NITRATE AND AMMONIUM NUTRIENT SOLUTIONS
}

\author{
SEDIBE, M. M. \\ Central University of Technology, Free State, Department of Agriculture, Private Bag X 20539, \\ Bloemfontein 9301, South Africa \\ (e-mail:msedibe@cut.ac.za; phone: +27-51-507-4054) \\ (Received $29^{\text {th }}$ Jun 2020; accepted $17^{\text {th }}$ Sep 2020)
}

\begin{abstract}
The objective of this study was to evaluate the effects of nitrate $\left(\mathrm{NO}_{3}{ }^{-}\right)$and ammonium $\left(\mathrm{NH}_{4}{ }^{+}\right)$ on the yield, mineral content and oil quality of rose geranium. Nitrate, at concentrations between eight and 14 meq $\mathrm{L}^{-1}$, and, ammonium at concentrations between 0.0 and $1.5 \mathrm{meq} \mathrm{L}^{-1}$, was applied to rose geranium. Nitrate $\left(10\right.$ meq $\left.\mathrm{L}^{-1}\right)$ produced the most significant increase in plant height, foliar fresh mass, foliar dry mass, oil yield and oil content. Ammonium applied at $1.0 \mathrm{meq} \mathrm{L}^{-1}$ had no significant effects on agronomicrelated attributes (e.g. plant height, foliar fresh mass, and foliar dry mass, etc.), only folia $\mathrm{N}(5 \%), \mathrm{P}(10 \%)$ and S (22\%) levels were increased. Principal component analysis was used to reduce the redundancy of the $\mathrm{NO}_{3}{ }^{-}$and $\mathrm{NH}_{4}{ }^{+}$data, and the eigenvalue of the correlation matrix. For the $\mathrm{NO}_{3}{ }^{-}$study, $\mathrm{PC} 1$ and $\mathrm{PC} 2$ accounted for most of the variability, showing a cumulative variability $>55.5 \%$ : $\mathrm{PC} 1$ accounted for $42.20 \%$, while PC2 accounted for $13.31 \%$ of the total variance. For $\mathrm{NH}_{4}{ }^{+}, \mathrm{PC} 1$ and $\mathrm{PC} 2$ accounted for most of the variability, with a cumulative variability $>47.1 \%$ : PC1 accounted for $26.54 \%$, while PC2 accounted for $20.56 \%$ of the total variance. For successful cultivation of rose geraniums, nutrient solutions should contain optimal concentrations of $\mathrm{NO}_{3}{ }^{-}$and $\mathrm{NH}_{4}{ }^{+}$.
\end{abstract}

Keywords: chlorophyll, geranium oil, hydroponically, ion, mineral

\section{Introduction}

Production of rose geranium (Pelargonium graveolens L.) oil occurs in South Africa (Sedibe and Allemann, 2012); local producers export geranium oil to the USA, Japan, and Europe, with an annual income estimated between 34 and 57 million USD (DAFF, 2017). In South Africa, geranium oil is a key component in the production of many food and beverage products (Rao et al., 1996; Sedibe, 2012), and is an active ingredient in skin care products (Sedibe, 2012).

In order to obtain a profitable income, high quality standards of rose geranium oil have to be met. This is an on-going challenge for South African producers, since weather parameters such as temperature and rainfall affect oil quality and these effects are profound on geraniol, citronellol and citronellylformate compounds of rose geranium oil (Prakasa Rao et al., 1995). Growers mitigate the effects of weather by management of the plants' nutrient regime (Sedibe and Allemann, 2012; Nyakane et al., 2019).

Rose geraniums need between $100 \mathrm{~kg}$ to $200 \mathrm{~kg} \mathrm{~N} \mathrm{ha}^{-1}$, depending on the soil nutrient status (Singh et al., 1996, 1999; Ram et al., 2003; Araya et al., 2006). Nitrogen is the only nutrient element that can be formulated in ionic solution either as the cation $\left(\mathrm{NH}_{4}^{+}\right)$or the anion $\left(\mathrm{NO}_{3}{ }^{-}\right)$. For greenhouse crops, most of the $\mathrm{N}$ is supplied in the form of $\mathrm{NO}_{3}{ }^{-}$. However, small quantities of $\mathrm{NH}_{4}{ }^{+}$, are used by soil-less growers to acidify their nutrient solution, consequently preventing precipitating Fe and $\mathrm{Zn}$ (Combrink, 2019). The objective of this study was to evaluate the effects of $\mathrm{NO}_{3}{ }^{-}$and $\mathrm{NH}_{4}{ }^{+}$on the yield, the mineral content and the oil quality of rose geranium oil, using a multivariate principle component analysis (PCA). 


\section{Material and methods}

\section{Research site}

This trial was conducted in a greenhouse at the west campus facility at the University of the Free State in Bloemfontein, situated in the Free State province of South Africa. The site is at an altitude of $1351 \mathrm{~m}$ above sea level $\left(29^{\circ} 07^{\prime} 16.78^{\prime \prime} \mathrm{S}, 26^{\circ} 12^{\prime} 45.95^{\prime \prime} \mathrm{E}\right)$. A wet wall pad and two fan systems were used to control temperature to $\pm 26^{\circ}$ in the greenhouse.

\section{Experimental design}

Rose geranium cuttings were rooted for eight weeks by a commercial grower (Pico-gro, RSA) prior to planting. Plants were then planted in $5 \mathrm{~L}$ pots filled with $2 \mathrm{~mm}$ sterile silica sand. Plants were grown for five months during 2016 growing season. Each treatment was replicated five times in a randomised complete block design. Each experimental unit had eight pots containing one plant (Sedibe, 2012). Table 1 shows concentrations of each ion in the nutrient solutions, in order to fulfil the experimental concentrations, $\mathrm{NO}_{3}{ }^{-}$levels were applied at 8,10, 12 and 14 meq L $\mathrm{L}^{-1}$ concentrations and $\mathrm{NH}_{4}{ }^{+}$were applied using $0.0,0.5,1.0$ and 1.5 meq $\mathrm{L}^{-1}$ concentrations.

Table 1. Ion ratio used in the nutrient solutions to test the effect of $\mathrm{NO}_{3}^{-}$and $\mathrm{NH}_{4}^{+}$ concentrations on rose geranium growth and oil quality parameters

\begin{tabular}{c|c|c|c|c|c|c}
\hline \multicolumn{7}{c}{ Nitrate ion (meq L') } \\
\hline $\mathrm{NH}_{4}{ }^{+}$ & $\mathrm{K}^{+}$ & $\mathrm{Ca}^{2+}$ & $\mathrm{Mg}^{2+}$ & $\mathrm{NO}_{3}^{-}$ & $\mathrm{H}_{2} \mathrm{PO}_{4}^{-}$ & $\mathrm{SO}_{4}{ }^{-}$ \\
\hline 1.00 & 5.50 & 6.50 & 2.50 & 8.00 & 2.11 & 4.83 \\
1.00 & 5.50 & 6.50 & 2.50 & 10.00 & 1.50 & 3.44 \\
1.00 & 5.50 & 6.50 & 2.50 & 12.00 & 0.89 & 2.05 \\
1.00 & 5.50 & 6.50 & 2.50 & 14.00 & 0.28 & 0.66 \\
\hline \multicolumn{7}{l}{ Ammonium ion $\left(\mathbf{m e q ~ L}^{-1}\right)$} \\
\hline $\mathrm{NH}_{4}^{+}$ & $\mathrm{K}^{+}$ & $\mathrm{Ca}^{2+}$ & $\mathrm{Mg}^{2+}$ & $\mathrm{NO}_{3}^{-}$ & $\mathrm{H}_{2} \mathrm{PO}_{4}^{-}$ & $\mathrm{SO}_{4}{ }^{-}$ \\
\hline 0.00 & 5.88 & 6.95 & 2.67 & 10.00 & 1.50 & 3.44 \\
0.50 & 5.69 & 6.72 & 2.59 & 10.00 & 1.50 & 3.44 \\
1.00 & 5.50 & 6.50 & 2.50 & 10.00 & 1.50 & 3.44 \\
1.50 & 5.31 & 6.28 & 2.41 & 10.00 & 1.50 & 3.44 \\
\hline
\end{tabular}

A "drain-to-waste" drip system was used to fertigate all the pots, using four irrigation cycles per day, scheduled at 08:00, 11:30, 14:00 and 18:00 for $30 \mathrm{~min}$ (Sedibe et al., 2005). The emitter flow rate was set to $4 \mathrm{~L}_{\text {hour }}{ }^{-1}$. As plants developed and the demand for water and nutrients increased, volumes were increased to ensure that $10 \%$ to $25 \%$ solution drained-to-waste, to prevent salt accumulation in the potting bags (Combrink, 2019). A fresh solution was mixed every two weeks.

During the experimentation period no diseases occurred. Aphids were controlled with organophosphate, using levels prescribed for ornamentals in South Africa $\left(0.5 \mathrm{ml} \mathrm{L}^{-1}\right)$. A full cover spray was applied and then this application was repeated after three and six days, following the method of Nyakane et al. (2019) and Sedibe and Allemann (2012).

The nutrient solutions were maintained at $\mathrm{pH} 6.98( \pm 0.02)$, with electrical conductivity (EC) of $1.60( \pm 0.1) \mathrm{mS} \mathrm{cm}$. The EC level of the solution was maintained by proportionally lowering the concentrations of phosphate and sulphate with increased 
nitrate concentrations (Table 1). Micronutrients $\left(\mathrm{mg} \mathrm{L}^{-1}\right)$ used in all the experiments were 6.0 Fe; 0.21 B; 0.03 Cu; 0.2 Zn; 0.55 Mn; and 0.05 Mo (Sedibe and Allemann, 2012; Combrink, 2019). The nutrient solutions were made up in $1000 \mathrm{~L}$ tanks, which served as reservoirs for the treatments. The feeding water had an EC of $0.2 \mathrm{mS} \mathrm{cm}^{-1}$ and a $\mathrm{pH}$ of 6.92. Expressed as meq $\mathrm{L}^{-1}$, it contained $0.48 \mathrm{Na} ; 0.05 \mathrm{~K} ; 1.0 \mathrm{Ca} ; 0.45 \mathrm{Mg} ; 0.01 \mathrm{~N}$; $0.15 \mathrm{SO}_{4} ; 0.21 \mathrm{Cl}$; and a total alkalinity of $1.18\left(\mathrm{HCO}_{3}\right)$. The alkalinity was lowered to $0.04 \mathrm{meq} \mathrm{L}^{-1}$ by applying $60 \%$ nitric acid at $0.78 \mathrm{meq} \mathrm{L}^{-1}$.

Plant height, foliar fresh mass (FM), and foliar dry mass (DM) were measured at harvesting. DM was determined by drying the harvested material at $68^{\circ} \mathrm{C}$ for 72 hours. The dried leaves were milled to $0.25 \mathrm{~mm}$ diameter using a micro hammer mill (Culatti, Zurich) (Jones et al., 1991). These leaves were subsequently used for the analyses of Ca, $\mathrm{Mg}, \mathrm{P}, \mathrm{K}, \mathrm{S}$, and $\mathrm{N}$. Content of $\mathrm{Ca}, \mathrm{Mg}, \mathrm{P}$, and $\mathrm{K}$ in the plant tissue was determined using inductively coupled plasma optical emission spectrometry (ICP-OES) (Optima 4300 DV, PerkinElmer Inc. USA) (Van Maarschalkerweerde and Husted, 2015). Sulphur content was also determined by ICP-OES using an extract solution (ICP-OES; JY Horiba Ultima, USA) and set at a wavelength of $181.978 \mathrm{~nm}$ (Van Maarschalkerweerde and Husted, 2015). The chlorophyll content was determined from the upper six mature leaves on the crop, using a chlorophyll meter (Optisciences CCM 200, USA), following the procedure described by Chen and Black (1992).

Nitrogen content was determined following the Dumas combustion method in a Leco FP-528 combustion N analyser (LecoCorp. St. Joseph, MI, USA) (Matejovic, 1995; Etheridge et al., 1998). Fresh biomass ( $2 \mathrm{~kg}-5 \mathrm{~kg}$ ) was collected for the extraction of essential oil. The oil was extracted from the stem and leaves using water and steam distillation for one hour (Motsa et al., 2006) in a customised $5 \mathrm{~kg}$ test distiller (PA Pretorius). Oil quality was determined by gas chromatography (GC); an Aligent GC (FID; model $6890 \mathrm{~N}$ ) fitted with a $30 \mathrm{~mm} \times 0.25 \mathrm{~mm}$ DB-5 fused silica capillary column, and film thickness of $0.25 \mu \mathrm{m}$ (Novák et al., 2001; Adams, 2004).

\section{Statistical analysis}

Analyses of variance were conducted using the general linear model (GLM) procedure of statistical analysis system (SAS) version 9.3 (SAS, 2017). A regression analysis was also run using the SAS program. Significant results were analysed using Tukey's while Fischer's test was used to calculate the least significant difference test (LSD), described by Steel and Torrie (1980). Statistically significant differences between treatment means was determined at the $5 \%$ level of significance.

Basic formulae were used in performing PCA, by adjusting the data matrix, $X$, which consists of $n$ observations (rows) on $p$ variables (columns) as described by NCSS (2019).

The basic equation of PCA is, in matrix notation, given by:

$$
\mathrm{Y}=\mathrm{W} \mathrm{X}^{\prime}
$$

where $\mathrm{W}$ is a matrix of coefficients that is determined by PCA.

These equations are also written as:

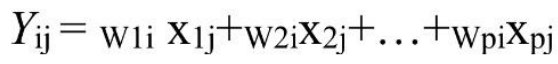


As seen, the components are a weighted average of the original variables. The weights, $W$, are constructed so that the variance of $y_{1}, \operatorname{Var}\left(y_{1}\right)$, is maximized. Also, so that $\operatorname{Var}\left(y_{2}\right)$ is maximized and that the correlation between $y_{1}$ and $y_{2}$ is zero. The remaining yi's are calculated so that their variances are maximized, subject to the constraint that the covariance between $y_{i}$ and $y_{j}$, for all $i$ and $j(i$ not equal to $j$ ), is zero.

\section{Results}

\section{Yield, mineral and oil quality attributes}

The yield attributes, mineral content and oil quality parameters of rose geranium are shown in Table 2. Plant height, FM, DM, oil yield and oil content were all significantly affected by nitrate content $(\mathrm{P}<0.05)$. The optimal $\mathrm{NO}_{3}{ }^{-}$level for all of these parameters was 10.0-12.0 meq L ${ }^{-1}$. Increases of 24\% (plant height,) $40 \%$ (FM), 50\% (DM), $60 \%$ (oil yield) and $17 \%$ (oil content) were observed at $10.0 \mathrm{NO}_{3}{ }^{-}$meq $\mathrm{L}^{-1}$. Only chlorophyll content had an optimal $\mathrm{NO}_{3}{ }^{-}$concentration that was significantly different $\left(12.0 \mathrm{meq} \mathrm{L}^{-1}\right.$; $\mathrm{P}<0.001)$. Geraniol and geranyl formate were significantly affected by $\mathrm{NO}_{3}{ }^{-}$, though the optimum concentration could not be established as concentrations varied in an inconsistent manner. The optimal $\mathrm{NO}_{3}{ }^{-}$concentration for citronellyl formate was also $10.0-12.0$ meq $\mathrm{L}^{-1}$, an increase of $8 \%$ compared to other treatments $(\mathrm{P}<0.05)$.

Table 2. Yield, mineral content and oil quality of rose geraniums cultivated using a nutrient solution with variable nitrate content

\begin{tabular}{|c|c|c|c|c|c|c|}
\hline $\begin{array}{l}\text { Nitrate } \\
\left(\operatorname{meq} \mathbf{L}^{-1}\right)\end{array}$ & $\begin{array}{c}\text { Plant height } \\
(\mathrm{cm})\end{array}$ & $\begin{array}{c}\text { Foliar fresh } \\
\text { mass } \\
\left(\mathrm{g} \mathrm{plant}^{-1}\right) \\
\end{array}$ & $\begin{array}{l}\text { Oil yield } \\
\left(\text { g plant }^{-1}\right)\end{array}$ & $\begin{array}{c}\text { Oil content } \\
(\%)\end{array}$ & $\begin{array}{c}\text { Foliar dry } \\
\text { mass } \\
\left(\text { g plant }^{-1}\right) \\
\end{array}$ & Chlorophyll \\
\hline 8.00 & $46.60 \pm 2.88^{c}$ & $585.00 \pm 112.64^{b}$ & $0.68 \pm 0.68^{b}$ & $0.12 \pm 0.04^{b}$ & $124.93 \pm 15.82^{b}$ & $18.33 \pm 0.74^{\mathrm{b}}$ \\
\hline 10.00 & $57.00 \pm 6.16^{b}$ & $820.20 \pm 159.63^{\mathrm{a}}$ & $1.09 \pm 1.09^{\mathrm{a}}$ & $0.14 \pm 0.02^{\mathrm{ab}}$ & $187.12 \pm 29.79^{\mathrm{a}}$ & $20.14 \pm 1.13^{b}$ \\
\hline 12.00 & $55.80 \pm 7.40^{\mathrm{ab}}$ & $822.80 \pm 59.44^{\mathrm{a}}$ & $1.16 \pm 1.16^{\mathrm{a}}$ & $0.14 \pm 0.04^{\mathrm{ab}}$ & $192.04 \pm 22.38^{\mathrm{a}}$ & $24.24 \pm 3.33^{\mathrm{a}}$ \\
\hline 14.00 & $49.40 \pm 1.67^{\mathrm{bc}}$ & $455.20 \pm 101.12^{\mathrm{b}}$ & $0.75 \pm 0.75^{\mathrm{b}}$ & $0.17 \pm 0.02^{\mathrm{a}}$ & $120.79 \pm 13.07^{b}$ & $23.13 \pm 1.49^{\mathrm{a}}$ \\
\hline $\mathrm{LSD}_{\mathrm{T} 0.05}$ & $7.10^{*}$ & $147.18^{* * *}$ & $0.26^{*}$ & $0.03^{*}$ & $29.80^{* * * *}$ & $2.87^{* * *}$ \\
\hline Nitrate & $\mathbf{N}$ & $\mathbf{P}$ & $\mathbf{K}$ & $\mathbf{C a}$ & Mg & $\mathbf{S}$ \\
\hline 8.00 & $3.36 \pm 0.22^{\mathrm{a}}$ & $0.51 \pm 0.06^{\mathrm{a}}$ & $2.91 \pm 0.31^{\mathrm{ab}}$ & $2.02 \pm 0.15^{\mathrm{a}}$ & $0.35 \pm 0.03^{\mathrm{a}}$ & $0.49 \pm 0.05^{\mathrm{a}}$ \\
\hline 10.00 & $3.39 \pm 012^{\mathrm{a}}$ & $0.43 \pm 0.02^{b}$ & $2.61 \pm 0.27^{b}$ & $1.77 \pm 0.89^{b}$ & $0.35 \pm 0.02^{\mathrm{a}}$ & $0.43 \pm 0.01^{\mathrm{a}}$ \\
\hline 12.00 & $3.35 \pm 0.08^{\mathrm{a}}$ & $0.38 \pm 0.03^{b}$ & $2.97 \pm 0.28^{\mathrm{a}}$ & $2.00 \pm 0.18^{\mathrm{a}}$ & $0.36 \pm 0.04^{\mathrm{a}}$ & $0.34 \pm 0.07^{\mathrm{b}}$ \\
\hline 14.00 & $3.39 \pm 0.37^{\mathrm{a}}$ & $0.27 \pm 0.03^{\mathrm{c}}$ & $2.78 \pm 0.26^{\mathrm{ab}}$ & $1.73 \pm 0.08^{b}$ & $0.21 \pm 0.01^{\mathrm{a}}$ & $0.26 \pm 0.03^{\mathrm{c}}$ \\
\hline $\mathrm{LSD}_{\mathrm{T} 0.05}$ & $0.35^{\mathrm{NS}}$ & $0.06^{* * *}$ & $0.32^{* *}$ & $0.19^{*}$ & $0.34^{\mathrm{NS}}$ & $0.08^{* * *}$ \\
\hline Nitrate & Linalool & Citronellol & Geraniol & $\begin{array}{c}\text { Citronellyl- } \\
\text { formate } \\
\end{array}$ & $\begin{array}{c}\text { Geranyl- } \\
\text { formate }\end{array}$ & Guaia6,9diene \\
\hline 8.00 & $1.96 \pm 1.09^{\mathrm{a}}$ & $31.91 \pm 1.22^{\mathrm{a}}$ & $13.94 \pm 0.88^{\mathrm{a}}$ & $19.66 \pm 2.07^{\mathrm{b}}$ & $8.61 \pm 1.03^{\mathrm{a}}$ & $9.69 \pm 0.71^{\mathrm{a}}$ \\
\hline 10.00 & $1.52 \pm 0.41^{\mathrm{a}}$ & $33.46 \pm 1.39^{\mathrm{a}}$ & $10.39 \pm 1.05^{\mathrm{b}}$ & $21.39 \pm 0.96^{\mathrm{ab}}$ & $7.98 \pm 0.45^{\mathrm{ab}}$ & $9.49 \pm 0.24^{\mathrm{a}}$ \\
\hline 12.00 & $1.89 \pm 0.61^{\mathrm{a}}$ & $32.31 \pm 1.87^{\mathrm{a}}$ & $10.25 \pm 0.63^{b}$ & $22.31 \pm 0.48^{\mathrm{a}}$ & $7.47 \pm 0.44^{b}$ & $10.39 \pm 0.54^{\mathrm{a}}$ \\
\hline 14.00 & $1.25 \pm 1.18^{\mathrm{a}}$ & $31.50 \pm 1.50^{\mathrm{a}}$ & $12.87 \pm 1.32^{\mathrm{a}}$ & $20.20 \pm 1.36^{b}$ & $8.44 \pm 0.28^{\mathrm{a}}$ & $10.17 \pm 0.59^{a}$ \\
\hline $\mathrm{LSD}_{\mathrm{T} 0.05}$ & $0.72^{\mathrm{NS}}$ & $2.17^{\mathrm{NS}}$ & $1.40^{* * * *}$ & $1.87^{*}$ & $0.85^{*}$ & $0.74^{\mathrm{NS}}$ \\
\hline
\end{tabular}

NS not significant at $\mathrm{P}<0.05$; *significant at $\mathrm{P}<0.05$; ** significant at $\mathrm{P}<0.01$; *** significant at $\mathrm{P}<0.001$. Means ( \pm standard deviation). The same superscript letter within a column denotes non significance $(\mathrm{P}>0.05)$ 
As shown in Table 3, ammonium had no significant effect on agronomic-related attributes (e.g. plant height, FM, DM, oil yield, oil and chlorophyll content). Significant changes were mostly observed on the foliar mineral contents. $\mathrm{NH}_{4}^{+}$at $1.0 \mathrm{meq} \mathrm{L}{ }^{-1}$ increased folia levels of N (5\%), P (10\%) and S (22\%). Foliar Mg content and linalool were also significantly affected by ammonium concentrations $(\mathrm{P}<0.05)$, but the optimal nutrient level was unclear. Citronellol, geraniol and citronellyl formate were not significantly affected by ammonium content $(\mathrm{P}>0.05)$. The optimal $\mathrm{NH}_{4}{ }^{+}$concentration for geranyl formate and guai6,9diene was 1.00 meq $\mathrm{L}^{-1} \quad(\mathrm{P}<0.01$ and $\mathrm{P}<0.05$, respectively).

Table 3. Yield, mineral content and oil quality of rose geraniums cultivated using a nutrient solution with variable ammonium content

\begin{tabular}{|c|c|c|c|c|c|c|}
\hline $\begin{array}{c}\text { Ammonium } \\
\left(\mathbf{m e q ~ L} \mathbf{L}^{-1}\right)\end{array}$ & \begin{tabular}{|c|}
$\begin{array}{c}\text { Plant height } \\
(\mathrm{cm})\end{array}$ \\
\end{tabular} & \begin{tabular}{|c|}
$\begin{array}{c}\text { Foliar fresh mass } \\
\left(\text { g plant }^{-1}\right)\end{array}$ \\
\end{tabular} & $\begin{array}{c}\text { Oil yield } \\
\left(\text { g plant }^{-1}\right)\end{array}$ & $\begin{array}{c}\text { Oil content } \\
(\%)\end{array}$ & $\begin{array}{c}\text { Foliar dry mass } \\
\left(\text { g plant }^{-1}\right)\end{array}$ & Chlorophyll \\
\hline 0.00 & $67.00 \pm 6.51^{\mathrm{a}}$ & $760.20 \pm 119.88^{a}$ & $0.85 \pm 0.18^{\mathrm{a}}$ & $0.112 \pm 0.02^{\mathrm{a}}$ & $170.34 \pm 8.92^{\mathrm{a}}$ & $21.90 \pm 1.51_{\mathrm{a}}$ \\
\hline 0.50 & $63.20 \pm 5.35^{\mathrm{a}}$ & $803.20 \pm 118.20^{\mathrm{a}}$ & $0.99 \pm 0.20^{\mathrm{a}}$ & $0.124 \pm 0.02^{\mathrm{a}}$ & $170.00 \pm 14.42^{\mathrm{a}}$ & $24.266 \pm 3.20^{\mathrm{a}}$ \\
\hline 1.00 & $60.20 \pm 5.80^{\mathrm{a}}$ & $790.40 \pm 90.50^{\mathrm{a}}$ & $1.00 \pm 0.11^{\mathrm{a}}$ & $0.127 \pm 0.12^{\mathrm{a}}$ & $158.28 \pm 14.02^{\mathrm{a}}$ & $26.17 \pm 4.155^{\mathrm{a}}$ \\
\hline 1.50 & $60.60 \pm 10.18^{\mathrm{a}}$ & $777.80 \pm 123.33^{\mathrm{a}}$ & $1.00 \pm 0.09^{\mathrm{a}}$ & $0.130 \pm 0.01^{\mathrm{a}}$ & $161.05 \pm 42.57^{\mathrm{a}}$ & $23.70 \pm 2.41^{\mathrm{a}}$ \\
\hline LSD $_{\text {T0.05 }}$ & $9.39^{\mathrm{NS}}$ & $168.53^{\mathrm{NS}}$ & $0.20^{\mathrm{NS}}$ & \begin{tabular}{|l|}
$0.01^{\mathrm{NS}}$ \\
\end{tabular} & $11.12^{\mathrm{NS}}$ & $4.41^{\mathrm{NS}}$ \\
\hline Ammonium & $\mathbf{N}$ & $\mathbf{P}$ & $\mathbf{K}$ & $\mathbf{C a}$ & Mg & $\mathbf{S}$ \\
\hline 0.00 & $3.12 \pm 0.14^{\mathrm{b}}$ & $0.40 \pm 0.01^{\mathrm{b}}$ & $2.29 \pm 0.15^{\mathrm{a}}$ & $1.77 \pm 0.10^{\mathrm{a}}$ & $0.37 \pm 0.01^{b}$ & $0.32 \pm 0.01^{\mathrm{c}}$ \\
\hline 0.50 & $3.11 \pm 0.16^{\mathrm{b}}$ & $0.41 \pm 0.03^{\mathrm{a}}$ & $2.53 \pm 0.24^{\mathrm{a}}$ & $1.74 \pm 0.11^{\mathrm{a}}$ & $0.40 \pm 0.02^{\mathrm{a}}$ & $0.33 \pm 0.05^{\mathrm{c}}$ \\
\hline 1.00 & $3.29 \pm 0.12^{\mathrm{a}}$ & $0.44 \pm 0.01^{\mathrm{a}}$ & $2.38 \pm 0.10^{\mathrm{a}}$ & $1.85 \pm 0.07^{\mathrm{a}}$ & $0.37 \pm 0.01^{\mathrm{b}}$ & $0.39 \pm 0.01^{\mathrm{b}}$ \\
\hline 1.50 & $3.31 \pm 0.17^{\mathrm{a}}$ & $0.40 \pm 0.03^{\mathrm{b}}$ & $2.40 \pm 0.14^{\mathrm{a}}$ & $1.76 \pm 0.12^{\mathrm{a}}$ & $0.30 \pm 0.01^{\mathrm{c}}$ & $0.43 \pm 0.02^{\mathrm{a}}$ \\
\hline $\mathrm{LSD}_{\mathrm{T} 0.05}$ & & & $0.23^{\mathrm{NS}}$ & $0.13^{\mathrm{NS}}$ & $0.02^{* * *}$ & \\
\hline Ammonium & Linalool & Citronellol & Geraniol & \begin{tabular}{|c|}
$\begin{array}{c}\text { Citronellyl- } \\
\text { formate }\end{array}$ \\
\end{tabular} & $\begin{array}{c}\text { Geranyl- } \\
\text { formate }\end{array}$ & Guaia6,9diene \\
\hline 0.00 & $1.77 \pm 0.28^{\mathrm{a}}$ & $33.46 \pm 2.32^{\mathrm{a}}$ & $12.68 \pm 1.22^{\mathrm{a}}$ & $20.48 \pm 0.34 \mathrm{a}$ & $9.18 \pm 0.58^{\mathrm{ab}}$ & $9.17 \pm 0.61^{b}$ \\
\hline 0.50 & $1.80 \pm 0.36^{\mathrm{a}}$ & $33.38 \pm 1.09^{\mathrm{a}}$ & $11.78 \pm 1.03^{\mathrm{a}}$ & $20.70 \pm 0.58 \mathrm{a}$ & $9.14 \pm 0.34^{\mathrm{ab}}$ & $9.16 \pm 0.42^{\mathrm{b}}$ \\
\hline 1.00 & $1.06 \pm 0.32^{b}$ & $31.86 \pm 1.14^{\mathrm{a}}$ & $10.82 \pm 2.31^{\mathrm{a}}$ & $20.65 \pm 2.39 \mathrm{a}$ & $9.97 \pm 0.68^{\mathrm{a}}$ & $10.27 \pm 0.69^{\mathrm{a}}$ \\
\hline 1.50 & $1.71 \pm 0.26^{\mathrm{a}}$ & $33.79 \pm 2.47^{\mathrm{a}}$ & $11.99 \pm 1.10^{\mathrm{a}}$ & $20.36 \pm 1.90 \mathrm{a}$ & $8.58 \pm 0.75^{b}$ & $9.43 \pm 0.27^{\mathrm{b}}$ \\
\hline $\mathrm{LSD}_{\mathrm{T} 0.05}$ & $4.28^{*}$ & $2.75^{\mathrm{NS}}$ & $2.16^{\mathrm{NS}}$ & $2.41^{\mathrm{NS}}$ & $0.88^{* *}$ & $0.69^{* *}$ \\
\hline
\end{tabular}

NS not significant at $\mathrm{P}<0.05$; *significant at $\mathrm{P}<0.05$; ** significant at $\mathrm{P}<0.01$; *** significant at $\mathrm{P}<0.001$. Means ( \pm standard deviation). The same superscript letter within a column denotes non significance $(\mathrm{P}>0.05)$

\section{Nitrate and ammonium principal component analysis}

Table 4 shows the PCA used to reduce the redundancy of the $\mathrm{NO}_{3}{ }^{-}$and $\mathrm{NH}_{4}{ }^{+}$data, and the eigenvalue of correlation matrix. Table 4 and Fig. $1 B$ show that for the nitrate treatment, out of nineteen principal components (PC) used, the first two (PC1 and PC2) accounted for most of the variability, with a cumulative variability $>55.5 \%$. PC1 accounted for $42.2 \%$, while PC2 accounted for $13.31 \%$ of the total variance. Table 4 and Fig. $1 B$ show that plant height, FM, oil yield, DM, total biomass, citronellol, geraniol and $\mathrm{Mg}$ content were loaded positively on $\mathrm{PC} 1$, however linalool, $\mathrm{Ca}, \mathrm{P}$ and $\mathrm{S}$ were loaded on PC2. This confirms that the majority of the tested variables were significantly affected by $\mathrm{NO}_{3}^{-}$levels between 10 and $12 \mathrm{meq} \mathrm{L}^{-1}$. Geraniol was the only compound was positively affected by the application of $\mathrm{NO}_{3}{ }^{-}$at $8 \mathrm{meq} \mathrm{L}^{-1}$. 
Table 4. Eigenvalues and principal component factor loading of parameters affected by nitrate and ammonium

\begin{tabular}{|c|c|c|c|c|c|c|c|}
\hline \multicolumn{4}{|c|}{ Nitrate } & \multicolumn{4}{|c|}{ Ammonium } \\
\hline $\begin{array}{l}\text { Principal } \\
\text { component }\end{array}$ & $\mathrm{PC} 1$ & $\mathrm{PC} 2$ & PC3 & $\begin{array}{l}\text { Principal } \\
\text { component }\end{array}$ & PC1 & $\mathrm{PC} 2$ & PC3 \\
\hline Eigenvalue & 13.083 & 4.125 & 2.652 & Eigenvalue & 7.433 & 5.757 & 3.475 \\
\hline$\%$ of variance & 42.204 & 13.307 & 8.555 & $\%$ of variance & 26.545 & 20.561 & 12.409 \\
\hline $\begin{array}{c}\text { Cumulative } \% \text { of } \\
\text { total variance }\end{array}$ & 42.204 & 55.511 & 64.066 & $\begin{array}{c}\text { Cumulative } \% \text { of } \\
\text { total variance }\end{array}$ & 26.545 & 47.106 & 59.515 \\
\hline \multicolumn{4}{|c|}{ Factor loadings } & \multicolumn{4}{|c|}{ Factor loadings } \\
\hline Height & 0.398 & 0.099 & 0.130 & Height & 0.289 & 0.214 & 0.018 \\
\hline $\begin{array}{l}\text { Foliar fresh } \\
\text { mass }\end{array}$ & 0.704 & 0.164 & 0.000 & $\begin{array}{l}\text { Foliar fresh } \\
\text { mass }\end{array}$ & 0.583 & 0.028 & 0.092 \\
\hline Oil yield & 0.665 & 0.000 & 0.257 & Oil yield & 0.187 & 0.694 & 0.026 \\
\hline Oil content & 0.002 & 0.338 & 0.434 & Oil content & 0.050 & 0.652 & 0.009 \\
\hline Foliar dry mass & 0.862 & 0.000 & 0.013 & Foliar dry mass & 0.726 & 0.081 & 0.043 \\
\hline Total biomass & 0.903 & 0.005 & 0.007 & Total biomass & 0.736 & 0.144 & 0.089 \\
\hline Chlorophyll & 0.102 & 0.297 & 0.069 & Chlorophyll & 0.008 & 0.329 & 0.065 \\
\hline Linalool & 0.000 & 0.293 & 0.219 & Linalool & 0.070 & 0.408 & 0.226 \\
\hline isoMenthone & 0.046 & 0.181 & 0.011 & isoMenthone & 0.001 & 0.146 & 0.002 \\
\hline Citronellol (C) & 0.272 & 0.143 & 0.015 & Citronellol (C) & 0.316 & 0.018 & 0.175 \\
\hline Geraniol (G) & 0.572 & 0.089 & 0.114 & Geraniol (G) & 0.080 & 0.236 & 0.107 \\
\hline $\begin{array}{l}\text { Citronellyl- } \\
\text { formate }\end{array}$ & 0.269 & 0.188 & 0.025 & $\begin{array}{l}\text { Citronellyl- } \\
\text { formate }\end{array}$ & 0.001 & 0.053 & 0.012 \\
\hline Geranyl-formate & 0.347 & 0.038 & 0.127 & Geranyl-formate & 0.204 & 0.066 & 0.356 \\
\hline Guaia6,9diene & 0.000 & 0.024 & 0.220 & Guaia6,9diene & 0.011 & 0.178 & 0.210 \\
\hline C:G ratio & 0.668 & 0,029 & 0.071 & $\mathrm{C}: \mathrm{G}$ ratio & 0.200 & 0.203 & 0.033 \\
\hline $\mathrm{N}$ & 0,038 & 0,018 & 0.000 & $\mathrm{~N}$ & 0.006 & 0.011 & 0.304 \\
\hline $\mathrm{Mg}$ & 0.314 & 0.198 & 0.015 & $\mathrm{Mg}$ & 0.009 & 0.013 & 0.012 \\
\hline $\mathrm{Ca}$ & 0.054 & 0.236 & 0.002 & $\mathrm{Ca}$ & 0.097 & 0.012 & 0.613 \\
\hline $\mathrm{P}$ & 0.001 & 0.731 & 0.017 & $\mathrm{P}$ & 0.015 & 0.017 & 0.566 \\
\hline K & 0.004 & 0.084 & 0.013 & K & 0.086 & 0.044 & 0.003 \\
\hline$S$ & 0.005 & 0.587 & 0.018 & $S$ & 0.083 & 0.220 & 0.006 \\
\hline
\end{tabular}

Values in bold correspond to the factor with the greatest squared cosine

In the ammonium treatment, the first two principal components (PC1 and PC2) accounted for most of the variability, with a cumulative variability $>47.1 \%$. PC1 accounted for $26.54 \%$, while PC2 accounted for $20.56 \%$ of the total variance. Table 4 and Fig. $1 B$ show that plant height, FM, DM, total biomass, and citronellol were loaded at $\mathrm{PC} 1$, while, in contrast to the $\mathrm{NO}_{3}{ }^{-}$results, oil yield, oil content, chlorophyll and linalool were loaded on PC2. 

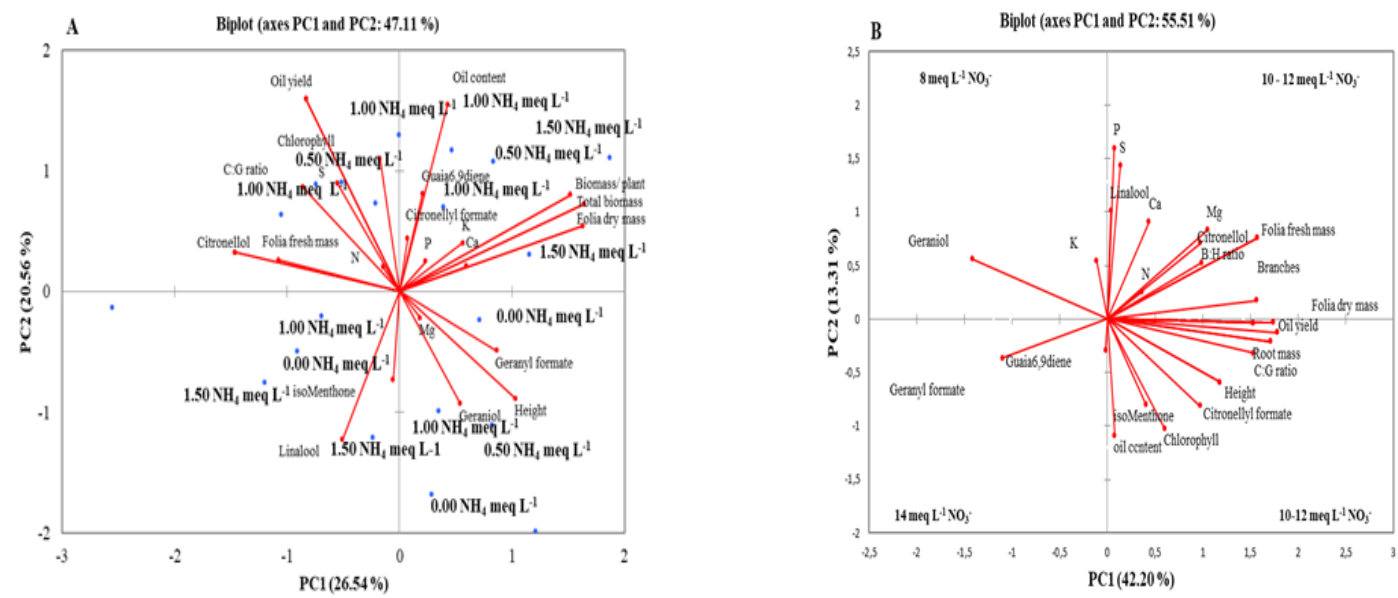

Figure 1. Rotated principal component analysis of measured yield, mineral and oil quality parameters of rose geraniums grown under $A)$ variable ammonium $\left(\mathrm{NH}_{4}^{+}\right)$concentrations; and B) variable nitrate $\left(\mathrm{NO}_{3}^{-}\right)$concentrations

\section{Discussion}

In South Africa, growers use both nitrate and ammonium in nutrient solutions as a source of $\mathrm{N}$, however, most of $\mathrm{N}$ comes from $\mathrm{NO}_{3}{ }^{-}$. Owing to its small size, and single charge ion, $\mathrm{NH}_{4}{ }^{+}$is easily absorbed by roots, resulting in the secretion of $\mathrm{H}^{+}$. However, it is often applied in smaller quantities, used mainly to reduce $\mathrm{pH}$ at the roots. In other countries, greenhouse crops are grown using nitrate as the sole $\mathrm{N}$ source, and the $\mathrm{pH}$ of these nutrient solutions tend to increase towards the root zone. Where organic substrates are used, bicarbonate is released during decomposition, thus increasing the alkalinity and raising the substrate $\mathrm{pH}$ (Benoit, 2003). Increasing the $\mathrm{NH}_{4}{ }^{+}$level can counteract this, especially on crops that are sensitive to Ca-deficiency (Combrink, 2019), however, Kafkaffi (2003) reported that damage by $\mathrm{NH}_{4}{ }^{+}$increases at high root zone temperatures. Ammonium is taken up by plant cells by means of $\mathrm{NH}_{4}{ }^{+}$transporters in the plasma membrane and distributed to intracellular compartments, such as chloroplasts, mitochondria and vacuoles (Howitt and Udvardi, 2000). The recommended optimum ratio of $\mathrm{NH}_{4}^{+}$to $\mathrm{NO}_{3}^{-}$for most summer crops is 1:10. For acid-loving crops, the recommendation is 1:1 (Pienaar, 2005; Combrink, 2019), and for blueberries it is 3:1 (Sonneveld, 2002; Combrink, 2019). Plant growth is impaired by using $\mathrm{NH}_{4}{ }^{+}$as the sole source of N (Claussen and Lenz, 1999).

The optimum $\mathrm{NO}_{3}{ }^{-}$concentration for most parameters measured in this study was between 10 and $12 \mathrm{meq} \mathrm{L}^{-1}$. Steiner's universal nutrient solution contains 12,1 and 7 meq $\mathrm{L}^{-1}$ of $\mathrm{NO}_{3}{ }^{-}, \mathrm{H}_{2} \mathrm{PO}_{4}$ and $\mathrm{SO}_{4}$, respectively (Steiner, 1984). Thus, nitrate represents $60 \%$ of Steiner' total anion application. In this trial the optimum anion ratio can be estimated at about $11 \mathrm{meq} \mathrm{L}^{-1}(74 \%)$, with $1.2 \mathrm{meq} \mathrm{H}_{2} \mathrm{PO}_{4} \mathrm{~L}^{-1}$ and $2.75 \mathrm{meq} \mathrm{SO} 4 \mathrm{~L}^{-1}$. The level of $\mathrm{NO}_{3}{ }^{-}$in rose geranium cultivation is crucial for optimising yield, in terms of height, FM, DM, oil and oil content, and for foliar content of P, K, S, geraniol, citronellyl-formate and geranyl-formate. Nitrogen promotes optimum plant growth by increasing cytokinin production. The synthesized cytokinin encourages cell wall elasticity, by increasing the number of meristematic cells, and cell growth (Razaq et al., 2017). 
There is a positive relationship between chlorophyll and N-content of the leaves (Abasi et al., 2016; Gholizadeha et al., 2017) and chlorophyll content can be used as an alternative measure for $\mathrm{N}$ status of most plant species (Fontes and de Araujo, 2006). This relationship between chlorophyll and foliar $\mathrm{N}$ content was not found in this study, possibly due to the increase in biomass production that occurred at increased nitrate levels. It is interesting to note that higher ammonium increased foliar $\mathrm{N}$ content and leaf chlorophyll was not affected.

It is known that high concentrations of $\mathrm{NH}_{4}{ }^{+}$in nutrient solutions may suppress the uptake of calcium (Abasi et al., 2016). In this study foliage Ca content was not affected by $\mathrm{NH}_{4}{ }^{+}$at levels of up to $1.5 \mathrm{meq} \mathrm{L}^{-1}$. Environmental conditions varied in the greenhouse that could have stimulated or suppressed transpiration, so causing differences in foliar $\mathrm{Ca}$ concentrations. As a result, as well as the fact that foliage $\mathrm{Ca}$ concentrations were well within limits for healthy plant growth (1.72\%-2.06\%), inconsistent effects of $\mathrm{NO}_{3}{ }^{-}$ concentrations on foliage Ca occurred. Calcium accumulation in plant tissues is affected by $\mathrm{Ca}$ uptake by the roots as well as the transpiration rate of the involved plant species. (Adams and Holder, 1992; Combrink, 2019). High humidity, high temperature, low temperature and low transpiration rates may induce $\mathrm{Ca}$ deficiency (Olle and Bender, 2009).

To ensure high herbage and oil yields, rose geraniums need to be grown at a relatively high nitrate concentration, of between 10 to $12 \mathrm{meq} \mathrm{L}^{-1}$. At these nitrate concentrations, plant height, FM, oil yield, DM, total biomass, citronellol, geraniol, C:G ratio and $\mathrm{Mg}$ content were loaded positively on PC1, however linalool, $\mathrm{Ca}, \mathrm{P}$ and $\mathrm{S}$ were loaded on PC2. The ammonium concentrations evaluated in this study had no effect on herbage and oil yield, but affected foliar N and S content. Given that some oil quality parameters were also affected by ammonium; this provides useful information to growers that $1.00 \mathrm{meq} \mathrm{L}^{-1}$ ammonium might be sufficient for hydroponically grown rose geraniums. The principal component analysis also revealed that plant height, FM, DM, total biomass, and citronellol were loaded at PC1, while oil yield, oil content, chlorophyll and linalool were loaded on PC2.

\section{Conclusion}

Unlike $\mathrm{NH}_{4}{ }^{+}$, a relatively high concentration of $\mathrm{NO}_{3}{ }^{-}$of 10 to $12 \mathrm{meq} \mathrm{L}^{-1}$ ensures high herbage and oil yields. Further investigation of the ratio of $\mathrm{NH}_{4}{ }^{+}$to $\mathrm{NO}_{3}{ }^{-}$is required for rose geranium grown using nutrient solution.

Acknowledgements. This work was supported by the Central University of Technology, Free State and the National Research Foundation- Thuthuka funding.

\section{REFERENCES}

[1] Abasi, H., Babalar, M., Lessani, H., Naderi, R. (2016): Effects of Nitrogen form of Nutrient Solution on Uptake and Concentration Macro Element and Morphological trait in Hydroponic tulip. - Journal of Plant Nutrition 39: 1745-1751.

[2] Adams, R. P. (2004): Identification of Essential Oil Components by Gas Chromotography/ Quadrupole Mass Spectroscopy. - Academic Press Inc., New York.

[3] Araya, H. T., Soundy, P., Steyn, M., Teubes, C., Learmonth, R. A., Mojela, N. (2006): Response of Herbage Yield, Essential Oil Yield and Composition of South African Rose- 
Scented Geranium (Pelargonium sp.) to Conventional and Organic Nitrogen. - Journal of Essential Oil Research 18: 111-115.

[4] Benoit, F. (2003): Workshop on Alternative Substrates. - Association of Vegetables Under Protection, Stellenbosch, RSA.

[5] Chen, J. M., Black, T. A. (1992): Defining Leaf Area Index for Non-Flat Leaves. Agricultural and Forest Meteorology 57: 1-12.

[6] Claussen, W., Lenz, F. (1999): Effect of Ammonium or Nitrate on Photosynthesis, Growth, and Activity of the Enzymes Nitrate Reductase and Glutamine Synthetase in Blueberry, Raspberry and Strawberry. - Plant and Soil 208: 95-102.

[7] Combrink, N. J. J. (2019): Nutrient Solutions and Greenhouse Management. - Combrink family trust, Stellenbosch, South Africa.

[8] DAFF (Department of Agriculture, Forestry and Fishery). (2017): A Profile of the South African Essential Oils Market Value Chain. - www.nda.agric.za/ doaDev/ sidemenu/ marketing/ annual.

[9] Etheridge, R. D., Pesti, G. M., Foster, E. H. (1998): A Comparison of Nitrogen Values Obtained Utilizing the Kjeldahl Nitrogen and Dumas Combustion Methodologies (Leco CNS 2000) on Samples Typical of an Animal Nutrition Analytical Laboratory. - Animal Feed Science Technology 73: 21-28.

[10] Gholizadeha, A., Saberioon, M., Borůvka, L., Wayayok, A., Soon, M. A. M. (2017): Leaf chlorophyll and nitrogen dynamics and their relationship to lowland rice yield for sitespecific paddy management. - Information Processing in Agriculture 4: 259-268.

[11] Howitt, S. M., Udvardi, M. K. (2000): Structure, Function and Regulation of Ammonium Transporters in Plants. - Biochimica et Biophysica Acta 1465: 152-170.

[12] Jones, J. B., Wolf, B., Mills, H. A. (1991): Plant Analysis Handbook. A Practical Sampling, Preparation, Analysis, and Interpreting Guide. - Micro-Macro Publishing, Georgia.

[13] Kafkaffi, U. (2003): Fertigation and nutrient solution management. - Association for Intensive Plant Production, Fertigation workshop, Stellenbosch University.

[14] Matejovic, I. (1995): Total Nitrogen in Plant Material Determined by Means of Dry Combustion: A Possible Alternative to Determination by Kjeldahl Digestion. Communications in Soil Science and Plant Analysis 26: 2217-2229.

[15] Motsa, N. M., Soundy, P., Steyn, J. M., Learmonth, R. A., Mojela, N., Teubes, C. (2006): Plant Shoot Age and Temperature Effects on Essential Oil Yield and Oil Composition of Rose-Scented Geranium (Pelargonium sp.) Grown in South Africa. - Journal of Essential Oil Research 18: 106-110.

[16] NCSS (2019): Principal Components Analysis. - NCSS Statistical Software, Chapter 425, Page 425, www.ncss.com.

[17] Novák, I., Zámboriné, N. É., Horváth, H., Seregély, Z., Kaffka, K. (2001): Evaluation of Essential Oils by Gas-Chromatography and a New Method: "Electronic Nose". International Journal of Horticultural Science 7: 85-89.

[18] Nyakane, N. E., Sedibe, M. M., Markus, E. (2019): Growth Response of Rose Geranium (Pelargonium graveolens L.) to Calcium: Magnesium Ratio, Magnetic Field, and Mycorrhizae. - HortScience 54(10): 1-7.

[19] Olle, M., Bender, I. (2009): Causes and control of calcium deficiency disorders in vegetables: A review. - Horticultural Science and Biotechnology 84: 577-584.

[20] Pienaar, D. (2005): A Study of Greenhouse Production Techniques for Evergreen Disas. MSc (Agric) thesis, University of Stellenbosch.

[21] Ram, M., Ram, D., Roy, S. K. (2003): Influence of an Organic Mulching on Fertilizer N Use Efficiency and Herb and Essential Oil Yields in Geranium (Pelargonium graveolens). - Bioresource Technology 87: 237-278.

[22] Rao, R. B. R., Kaul, P. N., Mallavarapu, G. R., Ramesh, S. (1996): Effect of Seasonal Climatic Changes on Biomass Yield and Terpenoid Composition of Rose Scented Geranium (Pelargonium sp.). - Biochemical Systematics and Ecology 24: 627-635. 
[23] Razaq, M., Zhang, P., Salahuddin, H. S. (2017): Influence of Nitrogen and Phosphorous on the Growth and Root morphology of Acer mono. - PlosOne 12(2): e171321.

[24] SAS (2017): SAS/STAT. Guide Version 9.2. - SAS, Institute incorporated. Raleigh, North Carolina, United States of America.

[25] Sedibe, M. M., Combrink, N. J. J., Reinten, E. Y. (2005): Leaf Yield of Amaranthus hypochondriatus L. (Imbuya), Affected by Irrigation Systems and Water Quality. - South African Journal of Plant Soil 22: 171-174.

[26] Sedibe, M. M. (2012): Yield and Quality Response of Hydroponically Grown Rose Geranium (Pelargonium spp.) to Changes in the Nutrient Solution and Shading. - PhD thesis, University of the Free State, South Africa.

[27] Sedibe, M. M., Allemann, J. (2012): Yield and Quality Response of Rose Geranium (Pelargonium graveolens L.) to Sulphur and Phosphorus Application. - South African Journal of Plant and Soil 29(3): 151-156.

[28] Singh, M., Chandrashekhara, R. S., Rao, G., Rao, E. V. S. (1996): Effect of Irrigation and Levels of Nitrogen on Herb Yield of Geranium (Pelargonium spp.) Under Semiarid Tropical India. - Journal of Essential Oil Research 8: 653-656.

[29] Singh, M. (1999): Effect of Soil Moisture Regime, Nitrogen and Modified Urea Materials on Yield and Quality of Geranium (Pelargonium graveolens) Grown in Alfisols. - Journal of Agricultural Science 133: 203-207.

[30] Sonneveld, C. (2002): Composition of Nutrient Solutions. - In: Savvas, D., Passam, H. (eds.) Hydroponic Production of Vegetables and Ornamentals. Embryo publications, Athens.

[31] Steel, R. G. D., Torrie, J. H. (1980): Principles and Procedures of Statistics: A Biometrical Approach. $-2^{\text {nd }}$ ed. McGraw-Hill, Kogakusha, Tokyo.

[32] Steiner, A. A. (1984): The Universal Nutrient Solution. - Proceedings of the International Society for Soilless Culture 1984: 633-649.

[33] Van Maarschalkerweerde, M., Husted, S. (2015): Recent Development in Fast Spectroscopy for Plant Mineral Analysis. - Frontiers in Plant Science 6: 169-183. 